\title{
Rapid resolution of acute epidural hematoma: case report and review of the literature
}

\author{
Hızlı rezolüsyon gösteren akut epidural hematom: \\ Olgu sunumu ve literatürün değerlendirilmesi
}

\author{
Habibullah DOLGUN, ${ }^{1}$ Erhan TÜRKOĞLU, ${ }^{1}$ Hayri KERTMEN,${ }^{1}$ Erdal Reşit YILMAZ, ${ }^{1}$ \\ Behzat Ruchan ERGUN, ${ }^{2}$ Zeki ŞEKERCi ${ }^{1}$
}

\begin{abstract}
Acute epidural hematomas present a serious and urgent condition. Standard management is early diagnosis and immediate surgical evacuation. Otherwise, there is a high risk of quick deterioration and death. Only patients with small asymptomatic epidural hematomas can be managed conservatively with close observation. We present a case of traumatic right temporal epidural hematoma. This is one of the rare cases of rapid spontaneous resolution of epidural hematomas within hours. Various possible mechanisms to explain the rapid resolution are discussed together with a review of the literature regarding the conservative treatment of epidural hematoma.
\end{abstract}

Key Words: Early resolution; cranial epidural hematoma; skull fracture.

Epidural hematoma (EDH) constitutes one of the most critical emergencies after traumatic head injury. Early diagnosis and fast evacuation are the standard management of this pathology. Advances in imaging techniques have enabled early and accurate diagnosis of EDH and can guide the operative treatment. Recently, non-operative treatment has been adopted in patients with subacute (3-14 days) and chronic (2 weeks and more) EDH. ${ }^{[1-3]}$ In a small group of patients, EDHs have rapidly disappeared in less than 24 hours. ${ }^{[4-6]}$ Many mechanisms of resolution have been reported, but exactly how the hematoma disappears remains unclear. $^{[5,7-10]}$

We report a case of EDH that disappeared rapidly without surgical evacuation.
Akut epidural hematomlar ciddi ve ağır klinik tablolardır. Erken tanı ve cerrahi boşaltma standart tedavi yaklaşımıdır. Aksi takdirde klinik tabloda hızla bozulma ve ölüm riski taşır. Asemptomatik küçük bir hasta grubu, yakın nörolojik ve radyolojik takip ile konservatif olarak tedavi edilebilir. Bu yazıda, 3 saat gibi kısa bir süre içerisinde rezolüsyon gösteren travmatik sağ temporal akut epidural hematom olgusu sunuldu. Bu olgu saatler içerisinde hızlı rezolüsyon görülen nadir olgulardan biridir. Çeşitli rezolüsyon mekanizmaları literatür verileri ışı̆̆ında tartışılmıştır.

Anahtar Sözcükler: Erken rezolüsyon; kraniyal epidural hematom; kafatası kırığı.

\footnotetext{
${ }^{1} 1$ st Department of Neurosurgery, Diskapi Yildirim Beyazit Training and Baysal University Faculty of Medicine, Bolu, Turkey.
}

\section{CASE REPORT}

A 27-year-old male fell from a height of approximately four meters. He was transported directly to our hospital emergency department by ambulance immediately after injury. On admission, his general condition was poor. He was agitated and had no cooperation or orientation. His pupils were equal and the reaction to light was bilaterally positive. He showed abnormal extremity flexion to pain. Systemic examination revealed right otorrhea and an evident subgaleal swelling on his right temporal region. He had stove-in chest, subcutaneous emphysema of the chest and neck, and open leg fractures bilaterally. Radiological evaluation revealed hemopneumothorax on the right side and tibia fractures bilaterally. His blood hemoglobin level was 


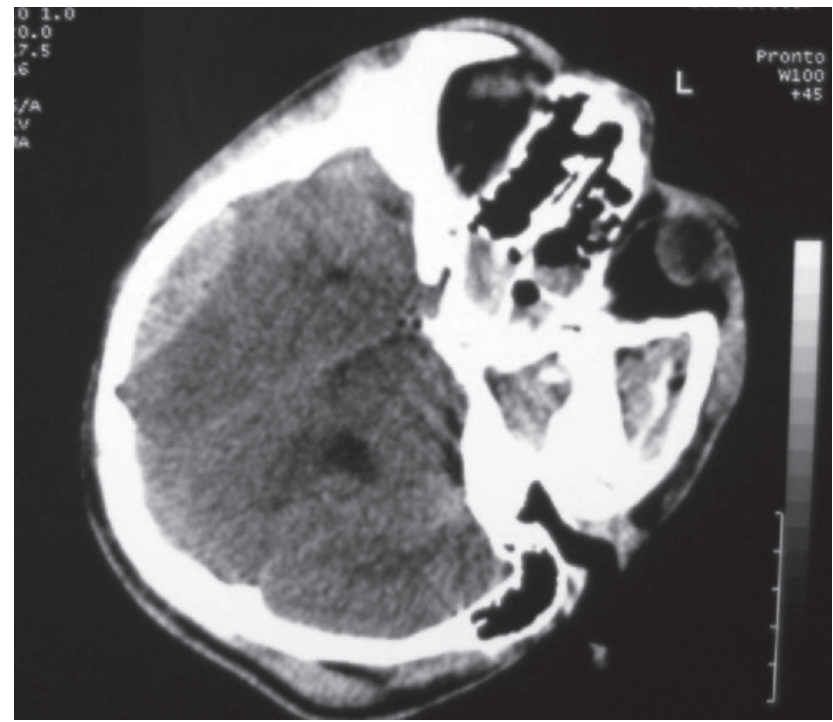

Fig. 1. Axial CT scan without contrast obtained on admission shows convex hematoma in the right epidural space.

$7.0 \mathrm{~g} / \mathrm{dl}$ and four units of erythrocyte suspension were transfused. His Glasgow Coma Scale (GCS) score was 7/15 because of serious injury and moderate head trauma. Chest tube thoracostomy was done to drain blood and air. The patient underwent urgent computerized tomography (CT). He was very agitated and active on the positioning table. The head of the patient was not turned while CT images were taken, but slight rotations to the left or right side went unnoticed by the emergency team. Consequently, we could not obtain standard CT images. The brain CT scan revealed a linear skull fracture on his right temporal bone, and an $\mathrm{EDH}$ of $1.2 \mathrm{~cm}$ thickness in the right temporal region (Fig. 1). The temporal linear fracture crossed the ex- ternal auditory canal. The patient was intubated and admitted to our intensive care unit and sedated. He was placed on intracranial pressure (ICP) monitoring, and ICP values were normal. There was a steady increase in otorrhea from the right ear. A third CT scan taken 3 hours after admission showed near total resolution of the hematoma (Fig. 2a, b). The patient's postinjury course did not improve and he died at the 24th hour of the injury as a result of accompanying pathologies such as hemopneumothorax and pulmonary contusion.

\section{DISCUSSION}

Epidural hematoma is generally managed with surgical treatment but non-operative treatment of EDHs has been argued. ${ }^{[4-10]}$ Weaver et al. ${ }^{[3]}$ first reported two EDH cases who showed spontaneous resolution. Nonoperative management of small hematomas has been proposed. The resolution biomechanism could be comparable to that of chronic subdural hematomas. The formation of a fibrovascular neomembrane lining the dural side acts as an absorbing structure for the blood clot. The angioblasts form sinusoids that gradually connect with the marginal dural vessels, so blood and blood products can return to the systemic circulation via the permeable membrane of these sinusoids. ${ }^{[1,5,6,11-13]}$ However, such hematoma resolution is reported as longer than three weeks. ${ }^{[6-8]}$ Medical treatment, repeated CT scan and close neurological follow-up are essential in the conservative management. ${ }^{[2-6,9-11,13]}$ In the present case, the EDH was not large enough to warrant absolute surgical intervention. Surprisingly, a very rapid spontaneous resolution of the hematoma was observed and this can be considered an extremely rare situation.
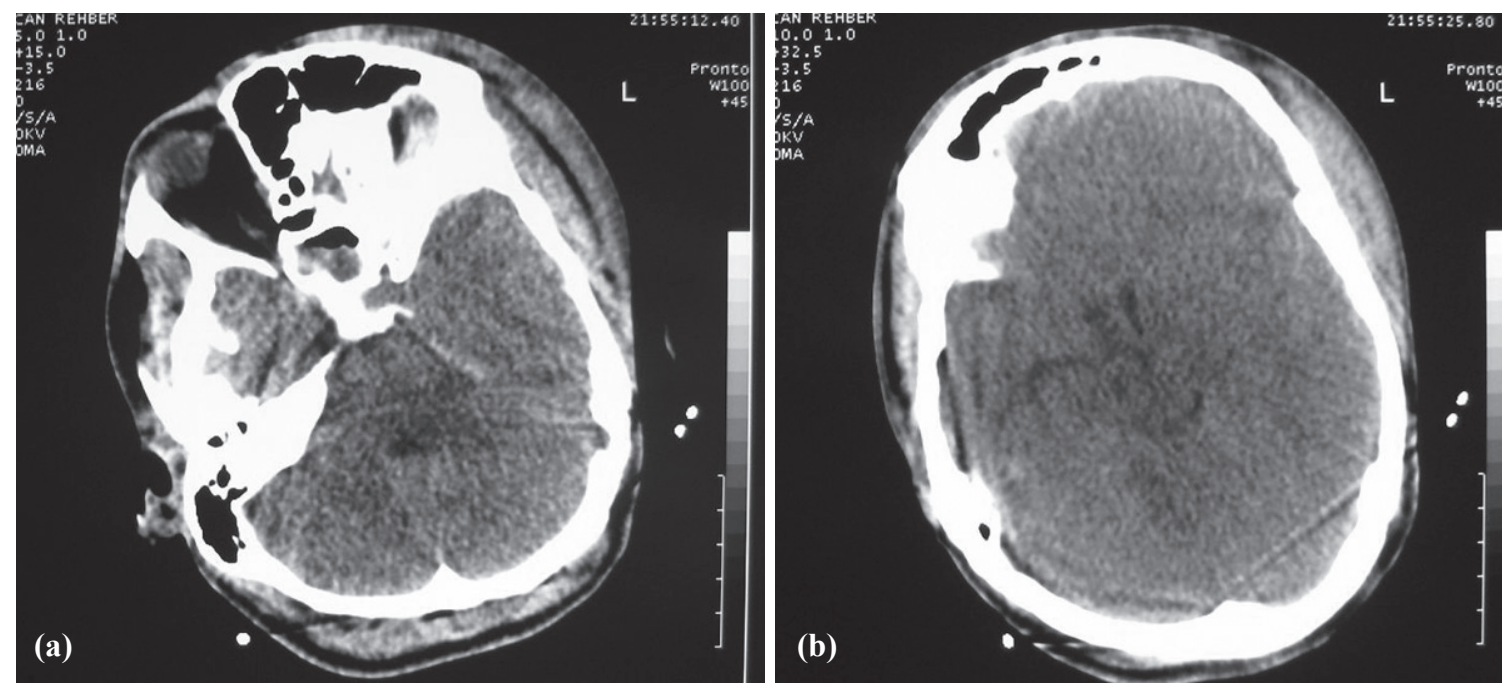

Fig. 2. (a) Same level axial CT scan as seen in Fig. 1 does not demonstrate epidural hematoma localization because the patient's head was not in the same position as in the first CT scan. The head was turned to nearly the opposite side, and the slice shows right mastoid cells and right orbita clearly. (b) Axial CT scan without contrast obtained 3 hours after injury shows almost total disappearance of the hematoma. This cross-section is not at the same level as seen in Fig. 1 because the patient's head position was altered on each CT slice. In fact, this slice shows the true epidural hematoma area, which had resolved almost totally in 3 hours. 
Table 1. Overview of several reports of acute resolution of epidural hematoma and possible mechanism of resolution

\begin{tabular}{lcclc}
\hline Authors & Year & Age/Sex & Resolution/mechanism & Time to resolution \\
\hline Aoki & 1988 & 8/M & Pressure gradient & $10 \mathrm{~h}$ \\
& & 17/M & Pressure gradient & $2 \mathrm{~h}$ \\
Servadei & 1989 & 65/M & Pressure induced redistribution & $4 \mathrm{~h}$ \\
Kuroiwa & 1993 & $17 / \mathrm{M}$ & Pressure gradient & $12 \mathrm{~h}$ \\
Malek & 1997 & $17 / \mathrm{M}$ & Elevated interstitial pressure in & \\
& & & the subgaleal compartment & $18 \mathrm{~h}$ \\
Ugarriza & 1999 & $43 / \mathrm{M}$ & EDH communicated with EAC & $6 \mathrm{~h}$ \\
Wagner & 2002 & $48 / \mathrm{M}$ & Pressure gradient & $1 \mathrm{~h}$ \\
Celikoglu & 2002 & $8 / \mathrm{M}$ & Pressure gradient & $1 \mathrm{~h}$ \\
Kang & 2005 & 34/M & Pressure gradient & $21 \mathrm{~h}$ \\
\hline
\end{tabular}

EAC: External auditory canal; EDH: Epidural hematoma; H: Hour; M: Male.

In the literature, various mechanisms related with early spontaneous resolution of EDH have been reported (Table 1). Some authors emphasized the potential communication between the intra and epicranial spaces through a fracture ${ }^{[4,14]}$ Increasing ICP creates a pressure gradient between the EDH and epicranial soft tissues, such that the EDH is forced out of the epidural space through the fracture. ${ }^{[2-6]}$ On follow-up CT scans, the changing density in pericranial soft tissues also supported this hypothesis. ${ }^{[5]}$ Another possible mechanism of the spontaneous resolution is the pressureinduced redistribution secondary to brain swelling, but dissipation of the hematoma seems harder because of tenacious adhesion between the dura mater and the skull. ${ }^{[5,8,9]}$ Malek et al. ${ }^{[8]}$ reported another mechanism that might be caused by an elevated epicranial subgaleal interstitial pressure after injury, in which extracranial blood collection or serous fluid could leak to the epidural space through a fracture because of the pressure gradient. When interstitial subgaleal pressure relaxed, the fluid leaked back. This process was completed in 18 hours. On the other hand, hyperacute resolution of EDH is a very rare phenomenon. ${ }^{[4,6,10]}$ Communication between the EDH and external auditory canal made ultra-early resolution possible without symptomatic intracranial hypertension. ${ }^{[11]}$ In the present case, CT scan revealed minimally displaced fracture of the temporal bone that crossed the auditory canal. In addition, there were no clear elevated ICP findings in the CT scan. We thought that the dura might have been torn and the hematoma liquified with the leak of cerebrospinal fluid through this small dural tear. In such a case, early drainage of the EDH might have been possible from the epidural space through the external auditory canal even without ICP elevation. This is the third case in the literature with a rapid resolution time of 3 hours (Table 1 ).

In conclusion, most EDH cases are treated surgically. Only patients with small asymptomatic EDHs can be managed conservatively with close observa- tion, and repeated CT scans are advised to facilitate surgical evacuation in case of deterioration.

\section{REFERENCES}

1. Pang D, Horton JA, Herron JM, Wilberger JE Jr, Vries JK. Nonsurgical management of extradural hematomas in children. J Neurosurg 1983;59:958-71.

2. Pozzati E, Tognetti F. Spontaneous healing of extradural hematomas: report of four cases. Neurosurgery 1984;14:724-7.

3. Weaver D, Pobereskin L, Jane JA. Spontaneous resolution of epidural hematomas. Report of two cases. J Neurosurg 1981;54:248-51.

4. Aoki N. Rapid resolution of acute epidural hematoma. Report of two cases. J Neurosurg 1988;68:149-51.

5. Kang SH, Chung YG, Lee HK. Rapid disappearance of acute posterior fossa epidural hematoma. Neurol Med Chir (Tokyo) 2005;45:462-3.

6. Kuroiwa T, Tanabe H, Takatsuka H, Arai M, Sakai N, Nagasawa $\mathrm{S}$, et al. Rapid spontaneous resolution of acute extradural and subdural hematomas. Case report. J Neurosurg 1993;78:126-8.

7. Akagami R, Cochrane DD. Does it leak in or does it leak out. Concerning the article by Malek et al., Pediatr Neurosurg 1997;26:160-165. Pediatr Neurosurg 1999;30:109-10.

8. Malek AM, Barnett FH, Schwartz MS, Scott RM. Spontaneous rapid resolution of an epidural hematoma associated with an overlying skull fracture and subgaleal hematoma in a 17-month-old child. Pediatr Neurosurg 1997;26:160-5.

9. Servadei F, Staffa G, Pozzati E, Piazza G. Rapid spontaneous disappearance of an acute extradural hematoma: case report. J Trauma 1989;29:880-2.

10. Celikoğlu E, Süsülü H, Delatioğlu M, Ceçen A, Hakan T, Bozbuğa M. Rapid spontaneous resolution of an acute epidural hematoma. Ulus Travma Derg 2002;8:126-8.

11. Ugarriza LF, Cabezudo JM, Fernandez-Portales I. Rapid spontaneous resolution of an acute extradural haematoma: case report. Br J Neurosurg 1999;13:604-5.

12. Sato S, Suzuki J. Ultrastructural observations of the capsule of chronic subdural hematoma in various clinical stages. J Neurosurg 1975;43:569-78.

13. Wagner A, Freudenstein D, Friese S, Duffner F. Possible mechanisms for rapid spontaneous resolution of acute epidural hematomas. Klin Neuroradiol 2002;12:45-50.

14. Chan KH, Mann KS, Yue CP, Fan YW, Cheung M. The significance of skull fracture in acute traumatic intracranial hematomas in adolescents: a prospective study. J Neurosurg 1990;72:189-94. 